\title{
GOVERNMENT CONTRACTS AND FAIR EMPLOYMENT PRACTICES
}

\author{
PAUL H. NoRgren*
}

\section{INTRODUCTION}

All procurement contracts of the federal government are required by presidential policy to include a provision committing the contractor not to discriminate against any employee or applicant for employment because of race, creed, color, or national origin. The policy was first laid down in an executive order issued by President Roosevelt in June $194{ }_{1}{ }^{1}$ in response to evidence of widespread discrimination against Negroes in filling jobs for expanding defense industries. Subsequent executive orders issued by Presidents Truman, Eisenhower, and Kennedy have kept the policy in continuous effect since that time.

The original Roosevelt order also provided for the establishment of a committee, appointed by the President, to secure compliance with the nondiscrimination requirement. This body, called the Fair Employment Practice Committee (FEPC), functioned during the early years of World War II. It was succeeded by another committee bearing the same name, which operated until the end of the war. During the seven ensuing years the policy of requiring nondiscrimination provisions in federal contracts remained in effect, but the executive order continuing it did not provide for any agency with overall responsibility for compliance. Early in 1952, however, the exigencies of the Korean War led President Truman to establish such an agency, titled the President's Committee on Government Contract Compliance (CGCC), which functioned only until the expiration of his term of office at the year's end. In August 1953, President Eisenhower issued an executive order creating a successor agency, called the President's Committee on Government Contracts (CGC), which remained in existence until the the termination of his administration at the end of r960.2 The succession was continued in March I96r, when President Kennedy, under a new and considerably broadened executive order, established the President's Committee on Equal Employment Opportunity (CEEO). ${ }^{3}$ As this is being written (December, 1963 ) the CEEO is still functioning, and President Johnson has stated that it will continue to do so with his full support.

The activities and experience of the World War II committees have been

- B.S. 1927, Worcester Polytechnic Institute; M.A. 1937, Ph.D. I940, Harvard University. Research Associate, Columbia University Seminar in Technology and Social Change. Formerly Director of Research Project on Minority Group Employment, Princeton University. Co-author, EMPLOYING THE Negro in American Industry (I959), Toward Fatr Employment (I964).

1 Exec. Order No. 8802, 6 Fed. Reg. 3201 (I94I).

${ }^{2}$ Exec. Order No. 10479, I8 Fed. 4899 (1953).

${ }^{8}$ Exec. Order No. ro925, 26 Fed. Reg. 1977 (196r). 
described and analyzed in considerable detail in earlier studies. ${ }^{4}$ Moreover, severe wartime manpower shortages prevailed throughout the period of their operation, and consequently their experience has only limited application to the problem of combating employment discrimination under present and prospective labor market conditions. The Truman Committee, in its few months of existence, did little more than study the problem of enforcing the nondiscrimination provision in general terms, and issue a report on its findings. 5

In contrast, the Eisenhower Committee on Government Contracts not only had the longest experience of any of the federal fair employment practice committees, but virtually all of its experience was gained under peacetime conditions. The KennedyJohnson Committee on Equal Employment Opportunity only recently began its third year of operation; hence it is still too early to obtain more than preliminary and spotty information concerning the results of its efforts. This paper, therefore, is devoted mainly to presenting a summary account of the activities of the Committee on Government Contracts during its seven-year career, and to appraising its effectiveness, as indicated by trends in the employment and occupational status of Negroes in federal contract establishments. In order to round out the picture of recent presidential efforts to combat employment discrimination, however, the paper also summarizes the activities of the Committee on Equal Employment Opportunity during its first two years of existence, and attempts a tentative assessment of its effectiveness as compared with the predecessor committee. ${ }^{6}$

\section{I}

\section{The Commitree on Government Contracts}

The CGC was known as an "interdepartmental committee," a designation that reflected both its membership composition and the arrangement for financing its operations. Its composition was defined in the executive order ${ }^{7}$ as follows:

Section 3.... (a) One representative of the following-named agencies to be designated by the respective heads of such agencies: the Atomic Energy Commission, the Department of Commerce, the Department of Defense, the Department of Justice, the Department of Labor, and the General Services Administration. (b) Eight other members to be appointed by the President. The Chairman and Vice Chairman shall be designated by the President.

The manner of providing operating funds for the CGC was prescribed thus:

Section 8. The government agencies (except the Department of Justice) designated in section 3(a) of this order shall defray such necessary expenses of the Committee as may

"Malcolm Ross, All Manner of Men (I948); Lous Ruchames, Race, Jobs and Politics (r953).

- President's Commitiee on Government Contract Compliance, Equal Economic Opportunity (1953).

Onformation concerning the activities and experience of the CGC and the CEEO was obtained chiefly through interviews with members and staff officials of the respective committees and with compliance offers in the Department of Defense, the General Services Administration, the Atomic Energy Commission, and other major contracting agencies.

${ }^{7}$ Exec. Order No. I0479, I8 Fed. Reg. 4899 (1953), reproduced in President's Comm. on Government Contracts, Five Years of Progress 32-33 (1958). 
be authorized by law ... provided that no agency shall supply more than fifty per cent of the funds necessary to carry out the purposes of this order.

This organizational arrangement was, in fact, the only alternative open to President Eisenhower. It was made necessary by the Russell Amendment, so named for its author, Senator Russell of Georgia. This amendment, attached to an appropriation bill for independent offices in 1944, prohibited the President from using funds available to him to pay the expenses of agencies created by executive order without the specific approval of Congress. ${ }^{8}$ It was expressly designed to terminate the second wartime FEPC and to prevent the establishment of a comparable agency in the future. The Eisenhower Administration, knowing that it would have been virtually impossible to obtain congressional approval of any nondiscrimination enforcement agency, therefore established the CGC as an interdepartmental committee, which did not require approval by Congress.

In line with the organizational setup of the CGC, the executive order made the head of each contracting agency primarily responsible for obtaining compliance with the nondiscrimination provision by contractors supplying his agency. ${ }^{9}$ The agency heads were instructed to take appropriate measures, "including but not limited to the establishment of compliance procedures," to carry out this responsibility. ${ }^{10}$ The Committee was directed "to receive complaints of alleged discrimination and transmit them to the appropriate contracting agencies for processing." Each contracting agency was to submit reports of action taken on all complaints received, which the Committee was directed to review and analyze. ${ }^{11}$

The remaining provisions of the executive order dealt mainly with ancillary duties of the Committee and the contracting agencies. Among other things, it authorized the Committee to "establish such rules as may be necessary for the performance of its functions under this order, and ... make annual or semi-annual reports on its progress to the President"; ${ }^{12}$ to "encourage the furtherance of an educational program by employer, labor, civic, educational and other voluntary nongovernmental groups in order to eliminate or reduce the basic causes and costs of discrimination in employment"; 13 and "to establish and maintain cooperative relationships with agencies of state and local governments, as well as with nongovernmental bodies, to assist in achieving the purposes of this order."14 The contracting agencies were "directed and authorized to cooperate with the Committee and, to the extent permitted by law, to furnish the Committee such information and assistance as it may require in the performance of its functions under this order."15

The government representatives named to the Committee were Vice President

${ }^{8} 58$ Stat. 387 (I944), 3I U.S.C. $\$ 696$ (I958).

- Exec. Order No. 10479, stupra note 7, § I.

${ }^{10} I d . \$ 2$.

${ }^{11} I d . \$ 5$.

${ }^{12} I d . \$ 4$.

${ }^{13} I d . \$ 6$.

${ }^{14} I d . \S 7$.

${ }^{16} I d . \$ 4$. 
Nixon, as chairman; the Secretary of Labor, as vice chairman; the Deputy Attorney General, and the second-ranking officers of each of the other four designated agencies. The "public" membership consisted of two labor union officials, four business executives, and the dean of a university law school.

Owing to its dependence on the contracting agencies for operating funds, the Committee was forced to operate on very limited annual budgets, ranging from $\$ 125,000$ in the early years to $\$ 375,000$ in I 960 . The CGC staff was of necessity correspondingly small, numbering some twenty persons of whom approximately half were professional-rank personnel. Additional operating manpower was supplied by the contracting agencies, which appointed "compliance officers" to handle the details of routing and processing complaints. Most of the persons so appointed, however, were engaged in contract administration work on a full-time basis. Since they were required to perform their complaint-processing duties in addition to their regular work, very few compliance officers devoted more than a small fraction of their time to compliance work.

During its first three years of operation the CGC concerned itself almost exclusively with complaints and with publicity and educational activities-the latter aimed chiefly at motivating Negroes and other minorities to train for skilled employment. The complaint-handling procedure, as outlined in the executive order and developed by the CGC and the contracting agencies, was extremely cumbersome. When a complaint was filed with the CGC, the staff first had to ascertain whether the firm complained against was actually engaged in federal contract work, and if so, with what agency. The complaint was then sent to the chief compliance officer in the contracting agency involved. Thence it went successively to regional and area offices, until it reached the contract officer assigned to the particular plant named in the complaint. The latter conducted an investigation and prepared a report setting forth his findings, which was then channeled back through the agency "layers" to the chief compliance officer and thence to the CGC. The staff analyzed the findings and prepared recommendations for disposition of the case, which were presented to the Committee itself for approval at its next monthly meeting. If the recommendations proposed corrective action, the case then went back to the contracting agency for implementation. When the agency considered that implementation had been accomplished, it so informed the CGC, which in turn informed the complainant of the action taken. The average time required to go through this entire process was nearly a year.

After about two years of experience under this unwieldy procedure, it became increasingly apparent that the processing of individual complaints was having little effect in bringing about compliance with the nondiscrimination provision. The number of complaints filed was extremely small, totaling only 147 in the first two years. And even in the rare case when a complaint was finally settled and the complainant redressed, correction of the discriminatory firm's overall practices did not necessarily follow. 
In 1955, therefore, the Committee addressed a memorandum to the contracting agencies, urging them to make a positive effort to obtain compliance with the nondiscrimination program rather than to rely entirely on complaints. Following this the Committee worked out an agreement with the agencies, committing them to conduct "inspections and field checks for compliance (in contractor establishments) on a sample basis." Other provisions of the agreement called for precontractual discussions with contractors regarding their obligations under the nondiscrimination provision, and for reporting systems to keep the Committee informed of action taken and progress made by the agencies. Investigation and conciliation of complaints were to be continued. 10

Owing to various delays in the agencies and in the CGC the agreed-upon "compliance survey" program did not get under way until i957. The procedure adopted, was to have agency personnel make on-the-ground racial employment pattern surveys in a small sample of contractor plants in cities having Negro populations of 50,000 or more. A small number of large plants outside these cities were also included in the sample. The total number of plants surveyed in 1957 was slightly over 500-a coverage of between two and three per cent of all plants holding federal contracts. In the two succeeding years the number surveyed dropped somewhat below 500 .

In 1957 the Committee also attempted to obtain acceptance by the agencies of the use of penalty pressure, on a very limited basis. The chairman wrote to the head of each contracting agency, requesting the adoption of "a firmer approach" in cases "where education, conciliation, mediation and persuasion do not bring proper results." The agencies were asked "to deny awards where there is convincing evidence of failure to comply with the nondiscrimination clause in previous contracts." They were also requested "to examine the employment practices of a firm not previously under contract by the government to determine if it has a record indicating that it will be able to comply with the nondiscrimination clause."17 However, no penalty was suggested for noncompliers in this category, nor did the Committee propose any penalties on noncomplying holders of ongoing contracts. And even the suggestion that new contracts be denied in cases of convincing evidence of past noncompliance proved abortive. During the entire career of the CGC no agency ever withheld an award or canceled an existing contract because of failure to comply with the nondiscrimination clause; and a thorough search has revealed only two instances of an agency even threatening to terminate a contract.

II

\section{Appraisal of the CGC EfFort}

While the compliance surveys covered only a small sample of all federal contract plants, the results of the surveys probably give a fairly good indication of the racial

${ }^{10}$ President's Comm. on Government Contracts, Second ANn. Rep. 2-4 (I956).

${ }^{17}$ Id., Fourth ANN. Rep. on EQUal Job OPPORTUNITY 7 (1957). 
employment pattern in government contract establishments generally during the latter half of the CGC's existence. The employment data obtained from the plants that were surveyed both in 1957 and 1959 are summarized below. (Figures from the I 660 survey are not available in comparable form.)

\begin{tabular}{lcc}
\multicolumn{3}{c}{ Negroes as Percentage of Total Employment in } \\
\multicolumn{3}{c}{ Selected Federal Contractor Plants } \\
Occupation Group & Negro Percentage of Total \\
& 1957 & 1959 \\
Professional and technical & 0.6 & 0.9 \\
Supervisory & 0.8 & 0.9 \\
Clerical & 0.6 & 1.0 \\
Skilled & 3.5 & 4.0 \\
Semiskilled & 12.7 & 11.6 \\
Unskilled & 18.2 & 18.7 \\
All others & 2.0 & 2.5
\end{tabular}

Source: Committee on Government Contracts, Tabulations of Employment by Race and Occupation Group in Plants of Federal Contractors, 1957-1959 (unpublished).

Two observations may be made concerning this tabulation. The proportion of Negroes increased in each of the four upper-level occupational categories between I957 and 1959, although the increases were small. On the other hand, the Negro percentages in these categories in I959 were substantially below the corresponding percentages for the nation at large, including both contractor and non-contractor establishments. Thus, for example, the proportion of Negroes among clerical workers in the country as a whole in I959 was 4.6 per cent as compared with only r.o per cent in these contractor plants. For skilled blue collar workers the figures were 4.8 and 4.0 per cent, respectively. ${ }^{18}$

Another survey of federal contractor establishments was conducted in six southern states in I 660 by the State Advisory Committees to the U.S. Commission on Civil Rights. This survey revealed that, of a total of 301 contractor firms in the six states, ninety-six per cent employed no Negroes at all in clerical or technical occupations, ninety-eight per cent employed none in sales, and ninety-two per cent employed none in supervisory positions. Nearly ninety per cent of these firms reported that contracting agency representatives had never talked with them about their racial employment practices. ${ }^{18}$

Investigations by the U.S. Commission on Civil Rights in three cities-Atlanta, Baltimore, and Detroit-in $x 960-6$ I revealed that

In most industries studied patterns of Negro employment by Federal contractors conformed to local industrial employment patterns. In the automotive industry, for example, even though each of the three manufacturers contacted had adopted a company-wide policy of nondiscrimination, employment patterns varied from city to city. In Detroit, Negroes

${ }^{18}$ U.S. Dep'T of Labor, The Economic Situation of Negroes in the United States 12 (1960).

${ }^{10}$ U.S. Comm'n on Crvil Rights, Negro Employment Practices in Private firms with federat Government Contracts Operating in Six Southern States-Kentucky, Louisiana, Nortir Carolina, South Carolina, Tennessee, and West Virginia 4 (mimeo. Ig6i). 
constituted a substantial proportion-from 20 to 30 percent-of the total work force. Although their representation in "nontraditional" jobs was slight, all companies employed them in all classifications other than management positions, and one company employed Negroes in administrative and management jobs as well. In Baltimore, each of the companies employed Negroes only in production work and not above the semiskilled level as assemblers, repairmen, inspectors and material handlers. In Atlanta the two automobile assembly plants contacted employed no Negroes in assembly operations. Except for one driver of an inside power truck, all Negro employees observed were engaged in janitorial work-sweeping, mopping, carrying away trash. Lack of qualified applicants cannot account for the absence of Negroes from automotive assembly jobs in Atlanta. . . The work is at most semiskilled and educational requirements are extremely low. ... 20

Taken together, the results of these surveys and investigations indicate that the activities of the CGC over a period of seven years failed to bring about any significant improvement in the employment status of Negroes in federal contract establishments. The salient handicaps and weaknesses that account for its failure are fairly apparent.

In the first place, the Committee, in seeking to enforce compliance with the nondiscrimination provision, could not deal directly with noncomplying employers. It could formulate policies and procedures for achieving compliance, but it was obliged to depend on the contracting agencies to conduct any actual dealings with contractor firms aimed at eliminating employment inequality in their operations. As a result, the entire compliance process was exceedingly cumbersome and inefficient. Moreover, there was a pervasive tendency among the contracting agencies to give first priority to obtaining fulfillment of their contracts, whenever insistence on compliance appeared to conflict with this objective.

Second, the compliance effort was focused primarily on processing and redressing individual complaints of discriminatory treatment. Little attention was given to eliminating overall discriminatory practices. Even after the CGC and the contracting agencies concluded the agreement providing for compliance surveys and greater emphasis on racial employment patterns, little effort was made to correct overall practices in noncomplying establishments.

Third, the entire CGC effort was based exclusively on using voluntary approaches and methods to bring about compliance with the nondiscrimination policy. Even the Committee's cautious proposal that renewal of contracts be denied in extreme cases of noncompliance was never invoked. The reliance on voluntary means was due in part to the fact that it is often impracticable to cancel or withhold contracts. Apart from this, however, the CGC preferred to avoid compulsion as a matter of principle.

Finally, the CGC made virtually no effort to deal with discriminatory labor organizations. Many local craft unions exclude Negroes from membership, and consequently Negro workers are often barred from employment opportunities solely

${ }^{20}$ U.S. Comm'n on Civil Righrs, I96I Report, Book 3, EMrployment $65-66$ (I96x). 
for this reason. The Committee, however, took the position that since unions are not direct parties to government procurement contracts, it had no authority to intervene in situations involving discriminatory union practices.

\section{III}

\section{The President's Committee on Equal Employment Opportunity}

The remainder of this paper deals with the President's Committee on Equal Employment Opportunity, established in March $196 \mathrm{r}$ by President Kennedy under Executive Order 10925.1 The CEEO is responsible for enforcing the presidential nondiscrimination policy both in federal contract establishments and in federal government agencies. The present discussion, however, is concerned only with its activities and experience as regards contractor employment.

The new executive order is much more detailed than that under which the CGC operated. It authorizes the contracting agencies to impose contractual requirements, make investigations and apply enforcement pressures and sanctions-powers not granted or at most only implied in the previous executive order. It provides for both a complaint-handling and a compliance reporting-and-reviewing system, whereas in the old order only complaint-handling was specified. Moreover, while the contracting agencies are still made primarily responsible for obtaining compliance by their contract holders, the Committee itself may assume "direct jurisdiction" in either complaint or compliance review situations, make investigations, and impose sanctions and penalties to secure compliance. ${ }^{22}$

Under the new order, as elaborated in the procedural regulations issued by the CEEO, all prime contractors and first-tier subcontractors are required to file "compliance reports" with the appropriate contracting agencies. These reports, showing employment by race and occupational category, as well as other racial employmentpattern information, must be filed within thirty days after the award of a contract, and annually thereafter. The contracting agencies may require prospective contractors to file compliance reports as an initial part of their bid, although the order does not make this mandatory. ${ }^{23}$ Provision is also made for "compliance reviews," designed "to ascertain the extent to which contractors and subcontractors are complying with the order. ..." These reviews are to be conducted through on-theground investigations by agency personnel. "Routine" compliance reviews, defined as "a normal part of contract administration," are to be conducted exclusively by the contracting agencies; but "special" compliance reviews, defined as "a comprehensive review of the employment practices of the contractor or subcontractor," may be conducted by the Committee itself. ${ }^{24}$

${ }^{21}$ Exec. Order No. 10925, 26 Fed. Reg. 1977 (1961).

${ }^{22} I d . \$ 309$.

${ }^{28} I d . \$ 302$.

24 President's Coms. on Equar Employment Opportunity, Rules and Regulations of the PresiDENT's Comm. on EquAl EMPLOYMENT Opportunity 9 (Ig6I). 
The initial step prescribed for dealing with noncomplying contractors in the new executive order is that "the contracting agency shall make reasonable efforts . . . to secure compliance . . . by methods of conference, conciliation, mediation, and persuasion." When these methods fail, the contracting agencies (or the Committee) may proceed to apply certain sanctions and penalties enumerated in the order. The two first listed, which may be called "pressure sanctions" to distinguish them from the actual penalties defined in subsequent provisions, are: (I) holding hearings, "public or private, as the Committee may deem advisable for compliance, enforcement, or educational purposes"; (2) publishing the names of contractors (or unions) which the Committee "has concluded have ... failed to comply with the provisions of this order...."25

The "penalty sanctions" which the contracting agencies (or the Committee) may impose are: ( $\mathrm{I}$ ) terminating all or part of any contract for failure of the contractor or subcontractor to comply; (2) refraining from entering into further contracts with any noncomplying contractor until he complies; (3) recommending to the Department of Justice that, in cases where there is "substantial violation or the threat of substantial violation," appropriate proceedings be brought to enforce the contractual provisions of the executive order. ${ }^{26}$

The new executive order also includes several provisions intended to combat discriminatory practices by labor organizations. While the order does not authorize direct action against unions, it requires contract-holders to furnish the CEEO with information regarding any practices and policies of unions they deal with which might prevent or militate against compliance. ${ }^{27}$ It also authorizes the Committee to utilize either or both of two pressure sanctions against unions that are preventing or hampering compliance, namely, to publish the names of such unions, and to hold public hearings with respect to their practices and policies. Further, the Committee is instructed to submit reports to the President concerning such unions, and is authorized to recommend remedial action. ${ }^{28}$

The CEEO, like the CGC in the preceding administration, is an "interdepartmental" body. The government representatives on the Committee include the Secretary of Labor, as Chairman, the Attorney General, the Secretaries of Commerce, Defense, the Army, the Navy, the Air Force, and Health, Education and Welfare; and the heads of the Atomic Energy Commission, the General Services Administration, the Civil Service Commission, and the National Aeronautics and Space Administration. The "public" membership is composed of fourteen private citizensincluding clergymen, union leaders, business executives, lawyers and housewivesnoted for their interest in civil rights. The full Committee meets only intermittently, primarily to discuss policy matters. (Seven meetings were held between March $196 \mathrm{r}$

\footnotetext{
${ }^{25}$ Exec. Order No. 10925, stupra note 3, $\$ 3$ I2.

${ }^{20}$ Ibid.

${ }_{27}$ Id. $\$ 302$.

${ }^{28} I d$. $\$ 305$.
} 
and November I962.) Responsibility for implementing the executive order is assigned to the operating staff, under the direction of the Executive Vice Chairman.

The CEEO's budget, like that of the predecessor body, is severely limited (\$425,000 in I962), and the operating staff is commensurately small, totaling only some thirty persons. Consequently it is forced to depend on the contracting agencies to carry out the compliance function, despite the fact that it is empowered to assume direct jurisdiction in dealing with noncomplying employers and unions. Some months after its establishment the Committee requested that the agencies add to their procurement staffs persons familiar with minority group problems to serve as compliance specialists. It based the request on the ground that a corps of such specialists would be able to promote compliance more effectively than the career contract-administration personnel assigned to this duty during the CGC's tenure. As of January 1963 , the contracting agencies were employing a total of thirty-seven compliance specialists.

A substantial proportion of the CEEO staff's time up to now has been devoted to the complaint-handling function. Complaints are processed by the contracting agencies as before, but the earlier procedure has been modified with a view to reducing the total processing time. Thus, for example, the Executive Vice Chairman is empowered to act for the Committee in making final decisions on the disposition of complaint cases. Assisting in the adjustment of complaints is one of the main duties of the compliance specialists now employed in several major contracting agencies.

In addition to dealing with complaints, the CEEO has given considerable attention to the problem of discriminatory general policies and practices in contractor establishments. One of the Committee's early actions was to implement the compliance reporting requirement provided for in the executive order. Firms awarded government contracts were instructed to submit initial reports beginning in March I962, showing the number of workers in each plant performing government work, by race and sex, in each of nine occupational categories; and similar reports annually thereafter. First-tier subcontractors were also required to file reports. These reports are designed to serve a double purpose: to aid in assessing the extent of individual contractors' compliance with the nondiscrimination provision, and to provide a statistical basis for gauging the effectiveness of the CEEO effort.

Soon after the establishment of the reporting procedure a second employment pattern-oriented compliance program, called "Plans for Progress," was launched. Under this program, which was conceived and promoted by Robert Troutman, an Atlanta lawyer and a member of the Committee, contractor companies are invited to sign pledges committing them to take "affirmative action" in all of their branches, plants, and divisions. They are asked to agree not merely to refrain from discriminatory employment practices, but to take positive steps to increase their recruitment and hiring of Negros and other minorities and to employ them in nontraditional positions. They are also asked to submit periodic reports, on forms supplied by the 
government, showing the degree of progress achieved in carrying out this objective. Participation in the program is entirely voluntary. However, the signatories are, of course, still bound by the mandatory nondiscrimination provision incorporated in all federal procurement contracts. As of January I, I963, 105 federal contractors, nearly all of them large multiplant companies, had signed Plans for Progress agreements.

The CEEO has also given some attention to the problem of racial discrimination by labor organizations. In the summer of 1962 it developed a program of nondiscriminatory policies for unions, similar to the Plans for Progress program for federal-contract employers announced some months earlier. The Committee asked the leaders of all national unions to sign pledges committing their organizations to follow the policies specified in the program, including acceptance of all eligible applicants for membership regardless of race or color, abolition of racially segregated local unions, and nondiscriminatory conduct of apprentice training plans. In November rg62, eighty-seven national labor organizations, all affiliates of the AFL-CIO, formally adopted the program; and at the time of writing the number of signatory unions had increased to more than Ioo. However, some seventeen national AFL-CIO affiliates and a number of unaffliated national organizations had either refused or failed to sign the pledge.

\section{IV}

\section{Appratsal of Early CEEO Experience}

Although the CEEO has been functioning for over two years, it is still too early to attempt more than a very tentative assessment of its effectiveness. A more definitive appraisal must await the accumulation of considerable further experience under the several compliance programs, and the receipt and tabulation of compliance reports from contractor establishments covering a period of several years.

With respect to processing and adjusting complaints the record of the CEEO is undoubtedly better than that of the CGC at the same stage of its career. While the new committee has received a larger volume of complaints, it has handled them more expeditiously, mainly as a result of modifications and short-cuts in the complainthandling procedure. Moreover, the CEEO has satisfactorily adjusted a considerably larger proportion of the complaints it has received.

The requirement for filing annual reports of racial employment patterns is an innovation with considerable potential as a tool for promoting compliance with the nondiscrimination policy. The mere prospect of having to file reports has probably caused some contractors to review and revise their hiring and placement practices. However, the reports could be used as a more direct and potent compliance aid through a systematic analysis of the employment information contained in them. Such an analysis would provide comprehensive factual information on the relative extent and degree of employment discrimination in different geographic areas, 
industries, and even individual firms and plants; and would therefore enable the Committee to plan and program its compliance effort more effectively, giving prior attention to those areas where discrimination was found to be most prevalent. However, the Committee had not begun to utilize the compliance reports for this purpose up to the time of preparing this paper.

There has been considerable controversy concerning the value of the Plans for Progress program. According to Committee spokesmen, the program has already brought important positive results. In August Ig62, Mr. Troutman reported on the effects of the Plans in thirty-seven of the signatory companies. He stated that over a six-month period following adoption of the Plans, employment of nonwhites in the thirty-seven firms increased by ten per cent, as compared with an increase in total employment of only 3.r per cent. He stated further that 6.6 per cent of the persons hired for salaried positions during the period were nonwhites, whereas only one per cent of such jobs were held by nonwhites at the beginning of the period. ${ }^{20}$

There is, however, considerable doubt as to whether such figures, summarizing changes in overall employment of a group of firms, constitute proof of the effectiveness of the Plans for Progress. Virtually all of the signatory companies are large multiplant organizations, with operations located mainly in northern and western states, where employment discrimination was already prohibited by state laws. The indicated gains might well have been concentrated in these operations; in any case, the overall employment figures give no indication of the effectiveness of the Plans in plants located in Southern states, where racial job inequality is particularly prevalent and where fair employment practice laws are nonexistent.

With these reservations in mind the Southern Regional Council, late in I962, conducted a survey of the Atlanta branch plants and offices of twenty-four Plans for Progress signatory companies. Only seven of the branches could produce any evidence of meaningful compliance with their pledges, and only three of theseLockheed, Western Electric, and Goodyear-had made any affirmative efforts to create opportunities for Negroes in nontraditional jobs. In the remaining seventeen branch operations the managements had either disregarded the pledges or professed ignorance of them. ${ }^{30}$ A survey of Plans for Progress signers, conducted by Fortune Magazine in twelve cities in July $\mathrm{I}_{96} \mathrm{C}_{3}$, revealed the same pattern of predominant noncompliance. ${ }^{31}$ Thus there is serious question as to whether the voluntary approach, as embodied in the Plans for Progress program, has produced any significant reduction in racial job inequality up to now.

On balance, the CEEO undoubtedly has a better record of accomplishment than its counterpart in the preceding administration. It is nonetheless apparent that it can never be more than a piecemeal and imperfectly effective instrumentality for combating job discrimination on a national scale. Despite the improvements embodied

\footnotetext{
${ }^{20}$ Southern Regional Councit, Plans for Progress: Atlanta Survey 5 (mimeo. 1963).

${ }^{80} I d$. at 8-9.

${ }^{31}$ Silberman, The Businessman and the Negro, Fortune, Sept. 1963, p. 99.
} 
in the new executive order, and its greater emphasis on eliminating discriminatory general practices and employment patterns, the CEEO suffers from a number of the same basic handicaps as the predecessor agency. Thus it is obliged to conduct its compliance efforts almost exclusively through the contracting agencies; and since the agencies' primary objective is to obtain fulfillment of contracts, enforcement of the nondiscrimination provision is bound to receive secondary consideration. Moreover, while the executive order provides for cancellation and withholding of contracts as penalties in dealing with recalcitrant employers, in most actual noncompliance situations it is impracticable to invoke these sanctions. And even where such penalties are feasible, the contracting agencies are usually extremely reluctant to effectuate them. It is significant that no contract has been cancelled or withheld for noncompliance since the CEEO was established.

Finally, while the CEEO may well continue to improve on the record of its predecessor, its total potential impact can be no greater, since its jurisdiction is confined to establishments holding federal contracts. Despite the great volume and variety of government purchases, these establishments comprise less than a third of the total private economy. Thus the CEEO, even at best, could eliminate discrimination in only a fraction of the nation's employing units. 